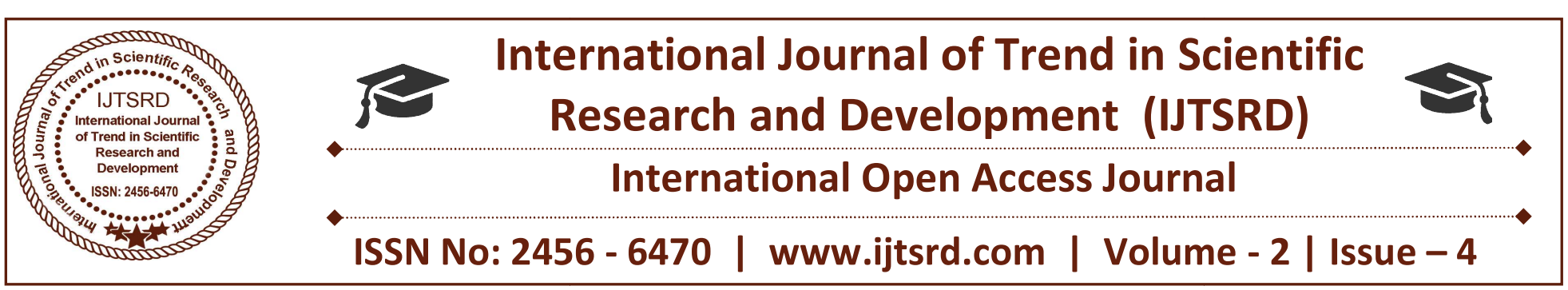

\title{
FDI in Indian Education Sector: An Analytical Study
}

\section{Arushi Chawla}

PG Student, Amity School of Economics, AUUP

\section{ABSTRACT}

In today's liberalised economy, FDI has a crucial role in the development of an economy. FDI is one the external factors affecting an economy's development whereas education is one of the internal factors that affects the economy. As per the census in 2011, literacy rate in India is 74\%. India has the $3 \mathrm{rd}$ largest higher education sector in the world after China and the U.S. Indian education sector has been acknowledged as the "Sunrise sector" for investment . With the increasing population of India, people's point of view regarding education has changed as well. On the other hand government and FDI in education sector plays an important role in it. India has emerged as a service based and knowledge based economy giving preference to growth of human capital. This paper analyses FDI trend in Indian education sector. The paper gives insight about the impact of FDI in Education onenrollment at secondary and higher level of education. Finally, it helps us understand how the combined efforts of India and other nations help in improving Indian education sector. The research approach is exploratory in nature. This paper has major implications for educationists who intend to reap the benefits of FDI as well as the Government who need to frame suitable policies.

Keywords: FDI, Higher Education, Government, enrollment

\section{INTRODUCTION}

Every country around the globe is trying to integrate its economy with the rest of the world. After globalization of Indian Economy there is a greater need of foreign capital in India. Indian education sector is one of the pillars of Indian Economy and many global players are willing to enter into it. Education sector has greater significance in developing countries like India. Increase in number of Educational Institutions in India has been remarkably rapid. India faces a big challenge to provide education to young people, especially in far-flung locations.

Foreign direct investment (FDI) is a direct investment in a country by an individual or company of another country, either by buying a company in the target country or by expanding operations of an existing business in that country. FDI mainly includes "mergers and acquisitions, reinvesting profits earned from overseas operations, intra company loans and building new facilities ". As a part of the national accounts of a country, and in regard to the GDP equation $\mathrm{Y}=\mathrm{C}+\mathrm{I}+\mathrm{G}+(\mathrm{X}-\mathrm{M})$ [Consumption + gross Investment + Government spending + (exports imports], where I is domestic investment plus foreign investment, FDI is defined as the net inflows of investment (inflow minus outflow) to acquire a lasting management interest in an enterprise operating in an economy other than that of the investor. FDI is the sum of equity capital, other long-term capital, and short-term capital as shown the balance of payments. FDI usually involves participation in management, joint-venture, transfer of technology and expertise. When categorised broadly, there are two types of FDI: outward and inward, resulting in a net FDI inflow (positive or negative). Direct investment excludes investment through purchase of shares.

In today's globalised world there is immense growth of FDI in both developed and developing countries. When considered for Developing countries, FDI is the safest source of external finance as it not only supplement foreign reserves, domestic savings but also promotes growth even more through spillovers of technology, skills, increased innovative capacity, and domestic competition. Now days, FDI has become an 
instrument of international economic integration. The FDI involves the transfer of technology and expertise, and participation in the joint venture and management.

\subsection{Discussion}

FDI in Education is not a new concept, since the economic reforms of 1991 which initiated liberalization FDI in education is has shown impact on Indian Education Sector. Many researchers have contributed toward the study of FDI in education and Indian Education Sector, few of the are as follows.

One of the recent study was presented by T.Greeshma, S.Ujwala, in 2017. Here author tries to analyse the need of FDI in higher education in India and to understand the post effect of FDI in Indian higher education system. The study is based on empirical data and is collected through various sources like journals, trusted sources and other studies on the similar grounds. The author concludes that it is important to state that India needs foreign direct investment to improve their higher education, through technical innovations and to stand first in gross enrolment ratio as well as $100 \%$ literacy rate should be enhanced. Regulatory bodies need to be framed by the Indian government to allow 100\% FDI and government should try to over-come the disadvantages. Ms. RidaShaikh\& Prof. Ajay Shukla Asst. Prof.: the authors objectifies to study education sector in India, to understand FDI in education sector, their pros and cons of FDI in education sector and to find solution to arguments against FDI in education. Secondary data was used for the research. Exploratory and analytical research was conducted analyse the issues relating to FDI in education sector. The research concludes that introduction of FDI in education sector is a correct opinion but it should include some norms. The successful premier foreign institutes should be given a chance to open university in India. Other foreign universities wanting to expand in India can work as subsidiary to Indian institutes or a separate self managed department in the existing institutes. These special institutes/ department should focus on skill developments that are required to compete globally. The foreign participants should be given freedom to frame their working pattern and model. This will ensure success in Indian Education Sector.

One of the study was given by Singh K., and Dr. AlkaAwasthi, in 2016 studied the 'Impact of FDI on
Higher Education' where the authors objectifies to analyse the current trends and patterns of flow of FDI towards education sector, to analyse the status of Indian higher education system and need of FDI in education sector in India and to examine the opportunities \& challenges of FDI in education sector in India. Moreover the paper tries to study the implications of bringing in FDI in Indian education, to trace out the barriers for FDI in Indian education and finally to suggest the removal of various barriers for FDI in Indian education system. The paper concludes that India badly require funds for the development of Education Sector as it is beyond the capability of country to serve the need of finance. In order to tackle this situation $100 \%$ FDI has been allowed by the Govt. but besides its advantages however there exists certain severe disadvantages which need strict action to be taken on the part of Indian govt. For that regulatory body should be framed otherwise India might face bad consequences in context of culture and autonomy of foreign education providers.

Moving further, VineySuhag; Kavita Rani in 2013 presented 'FDI and higher Education', here the authors presents argument in favour of FDI in education, that foreign institutions can bring quality programs with market orientation. The paper argued that FDI could promote competitiveness in the education system as a whole. Moreover, the critics maintain that the quality could be maintained in certain specific sectors, where FDI takes place, whereas in mass education sector the spillover effect of quality may not take place. Therefore, critics maintain that there should be no liberal FDI policy in education. In the same yearpapergiven by Lords Institute of Engineering and Technology, Hyderabad objectifies to study the trends and patterns of flow of FDI towards Indian Education Sector, to assess FDI as a determinant for growth of Education Sector and evaluate the impact of establishment of Foreign Universities in India. 4. Moreover, it throws light on the status of Indian higher education system and need of FDI in education sector in India, to study the opportunities of FDI in education sector in India. Finally, study the need of FDI in education in India. The analysis based on secondary sources of data. The authors concludes that Education industry in India is among the fastest growing industries of Indian economy, industry has benefited a lot from the Indian rapid economic growth coupled by the rising earnings levels in India. FDI is a vital factor in influencing the contemporary process of global economic 
development. And finally, ShilpaKaura, Former Asst. prof., Khalsa College for Women, Civil Lines, Ludhiana presented on 'FDI in Higher Education' which examines and reaccesses FDI in Education Sector. The paper provides a strategic analysis at the Indian higher education sector from the perspective of education in India's university. As per the findings, the paper concludes that government must consider serious corporatization of higher education of global standards. Moreover, it is understandable to keep primary and secondary school education as charity or social objective to enhance literacy rate to $100 \%$ level but higher education must be freed from his tag.

\subsection{Objective}

1. To study the relevance of FDI in Indian education sector and trend analysis of FDI in education and enrolment in primary, secondary and higher education.

2. To analyse the relationship between FDI in education and total enrolment at various levels of Education(secondary and higher). (2007-2015)

3. to analyse the impact of FDI in education and government expenditure on enrolment in higher education.

\subsection{Research Methodology}

Research methodology deals with a systematic and scientific methods that can be adopted to solve research problems. The study deals with quantitative methods of analysing the secondary data and concluding them into valuable findings. The first part is descriptive in nature.

For the second part the impact of FDI in Education on enrolment at secondary and higher levels of education. To study the impact simple linear regression were individually run where FDI in Education was taken as an independent variables and enrolment in primary, secondary and higher education are used as dependent variable.

For the third part the impact of FDI in Education and Gov't expenditure on enrolment at higher level of education. To study the impact multiple regression was run, where FDI on education and Gov't expenditure are independent variables and enrolment in higher education is dependable variable.
Lag of two years has been taken for second and third part.

\subsection{Limitation of research}

The data analysis under this paper is done assuming a 2 year lag. II Data analysis and Finding

\subsection{Trend of FDI in education at different levels of education}

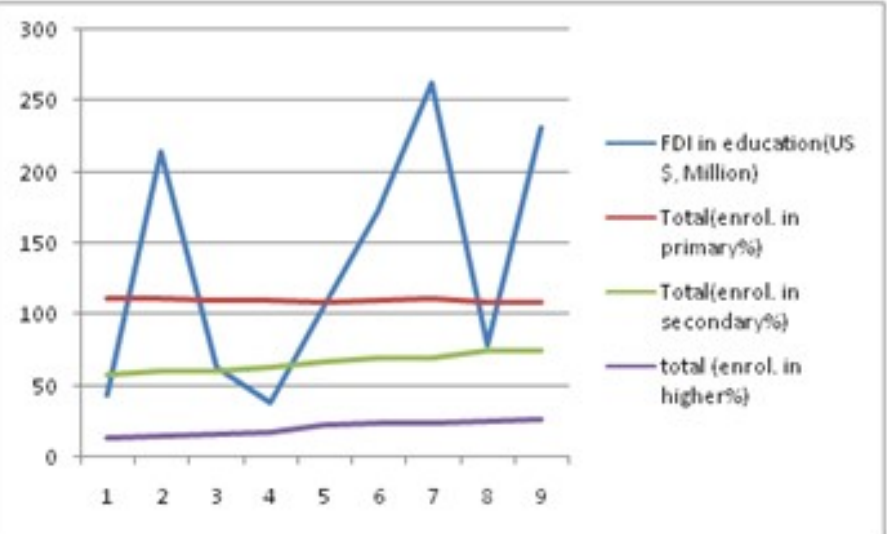

Source: open government data of India and UNESCO

The above trend clearly shows that firstly, there is not much change in enrolment at primary education, where whereas there is a slight rise in enrolment at secondary level of education. Finally. Enrolment at higher education level shows the highest positive change. Coming to FDI in education, it shoes fluctuation over the years. However, there has been a rise.

\subsection{Need of FDI in Indian Education Sector}

Education plays a critical role in good living and growth of everyone's life. If every citizen of the country is well educated then the future of the country is bright. Excellent education system helps in upgrading the country and takes it to the peak of success. In simple words, education is vital in every area to get success in the life. Education is the base for good economic system and for a better citizenship.

Ensuring proper basis in Indian Education System has been an aim for planning commission committee. In last few decades, there have been various steps taken by the government like " The Right to compulsory primary education act in 2009", "Reservation Act", and many more. The education system of India is right now is under renovation. The government aims in increasing the gross enrolment ratio from $15 \%$ to nearly double $30 \%$ at the end of 2020 . 
The Indian Educational System has enormous potential for growth. Indians have always considered knowledge as vital element for the growth and development of society. FDI will rejuvenate the Indian Educational System through forming an alliance with existing institutions and generation of funds for innovative programs. The Indian Education System gets a very small portion of the total national resources. FDI will solve problems related to scarcity of funds. It would help in setting up the institutes with high level of infrastructure in India and will improve the state of primary, secondary and higher secondary schools in India. Foreign Professors stocked with high practical knowledge can be allotted to share their quality experience with Indian students. As a result the education system could work towards coming at par with education provided in foreign institutes.

Till date several Indians enrolled in schools and universities do not have access to basic facilities like sports grounds and libraries. Lack of space and resources have contributed to the gloomy state of Indian Educational Sector. Broken benches and lack of blackboards are some of the problems which are being faced in many Indian educational institutions. FDI can have a huge impact on the future of the Indian educational system. Private and public funders have their own constraints. Private funding tends to be concentrated in urban areas and lucrative fields such as management. Public funds are limited which makes it difficult for state and central governments to maintain the vast number of Indian educational institutions. Major concern for India is the decrease in number of people returning to the native country for education. Migration of people has become a threat and to overcome this problem and arrest the flow of funds to the foreign countries it is feasible for the government to permit foreign universities to set up their campuses in India.

FDI in education sector will increase the number of institutions and ensure greater availability of opportunities to students. It will provide greater opportunities for efficient and effective utilization of improved infrastructure. This will further lead to competition which will help in improving the quality, innovative curriculum development and subject expertise. The access to latest technology and infrastructure will improve the growth in the research and development.

With FDI in Indian Education Sector it will initiate the opportunities to have access to many educational institutes of international standards in India. This will benefit the youth as every year a lot of students migrate to foreign institutes to pursue higher education. With the educational institutes having international standards in India, it will reduce the number of students migrating in pursue of education. Getting educated in native country will be better for students financially and emotionally as a lot of students take loan to pursue higher education in foreign institutes.

\subsection{Impact of FDI in education sector on enrolment in Secondary Education}

This section shows the impact of FDI in Education on enrolment at secondary level of Education. The Table given below shows FDI in Education Sector and enrolment in Secondary education (2007-2015)

The table given below shows FDI in Education Sector and enrolment in secondary education (2007-2015)

\begin{tabular}{|l|l|l|l|}
\hline Year & $\begin{array}{l}\text { FDI in } \\
\text { Education }\end{array}$ & Year & $\begin{array}{l}\text { Total( enrol. in } \\
\text { secondary\%) }\end{array}$ \\
\hline 2005 & 3.16 & 2007 & 57.48 \\
\hline 2006 & 41.81 & 2008 & 60.56 \\
\hline 2007 & 43.59 & 2009 & 59.79 \\
\hline 2008 & 214.52 & 2010 & 63.29 \\
\hline 2009 & 63.35 & 2011 & 66.42 \\
\hline 2010 & 37.94 & 2012 & 69.16 \\
\hline 2011 & 105.62 & 2013 & 68.9 \\
\hline 2012 & 172.2 & 2014 & 74.28 \\
\hline 2013 & 262.09 & 2015 & 73.97 \\
\hline
\end{tabular}

Source: open government data of India and UNESCO

\section{Research Hypothesis}

H0: There is no significant impact of FDI in education on Enrolment secondary education.

Ha: There is significant impact of FDI in Education on Enrolment Secondary Education.

The impact of FDI in education sector on enrolment in secondary education is measured with the help of simple linear regression analysis. The fixed regression model is

$\mathrm{Y}_{\mathrm{t}}=\mathrm{a}+\mathrm{bX} \mathrm{X}_{\mathrm{t}-2}$

Where, $Y=$ enrolment in Secondary education (\%), $\mathrm{X}=\mathrm{FDI}$ in Education $\mathrm{b}=$ Regression coefficient $\mathrm{a}=$ Constant

The results can be seen from table 2 
International Journal of Trend in Scientific Research and Development (IJTSRD) ISSN: 2456-6470

Table 2: FDI in education and enrolment in Secondary education

\begin{tabular}{|c|c|c|c|c|c|}
\hline Variables & $\begin{array}{c}\text { Coefficient } \\
\text { Beta }\end{array}$ & T-Value & P-Value & Correlation & $\mathbf{R}^{2}$ \\
\hline $\begin{array}{c}\text { FDI in } \\
\text { Indian } \\
\begin{array}{c}\text { Education } \\
\text { Sector }\end{array}\end{array}$ & 0.0438834 & 2.263 & 0.058039 & 0.65006559 & 0.422585 \\
\hline
\end{tabular}

Source: Author's own calculation compilation based on table1

There exists a weak but positive correlation $(\mathrm{r}=0.65)$ between FDI in education and enrolment in Secondary education. To measure the impact of FDI in education and enrolment in Secondary education a hypothesis was framed that "There is no significant impact of FDI in education and enrolment in Secondary education ". To test the above hypothesis regression tools were used. The regression coefficient of FDI in Education has positive impact on enrolment in secondary education i.e. $1 \%$ of change in FDI in Education will bring about 0.0438834 change in enrolment under Secondary education keeping other variables constant. The model is insignificant $(p>0.05)$ and the null hypothesis will be accepted which means the FDI in education do not have a significant impact on enrolment in Secondary education.

\subsection{Impact of FDI in education sector $/$ on enrolment in Higher Education}

This section shows the impact of FDI in Education on enrolment at Higher level of Education.The Table given below shows FDI in Education Sector and enrolment in Higher education (2007-2015).
Table 3: FDI in Education Sector and enrolment in Higher education (2007-2015)

\begin{tabular}{|l|l|l|l|}
\hline Year & $\begin{array}{l}\text { FDI in } \\
\text { Education }\end{array}$ & Year & $\begin{array}{l}\text { Total (enrol. in } \\
\text { higher\%) }\end{array}$ \\
\hline $\mathbf{2 0 0 5}$ & 3.16 & 2007 & 13.19 \\
\hline $\mathbf{2 0 0 6}$ & 41.81 & 2008 & 15.12 \\
\hline $\mathbf{2 0 0 7}$ & 43.59 & 2009 & 16.1 \\
\hline $\mathbf{2 0 0 8}$ & 214.52 & 2010 & 17.91 \\
\hline $\mathbf{2 0 0 9}$ & 63.35 & 2011 & 22.86 \\
\hline $\mathbf{2 0 1 0}$ & 37.94 & 2012 & 24.37 \\
\hline $\mathbf{2 0 1 1}$ & 105.62 & 2013 & 23.89 \\
\hline $\mathbf{2 0 1 2}$ & 172.2 & 2014 & 25.54 \\
\hline $\mathbf{2 0 1 3}$ & 262.09 & 2015 & 26.87 \\
\hline
\end{tabular}

Source: open government data of India and UNESCO

\section{Research hypothesis}

H0: There is no significant impact of FDI in education on Enrolment in Higher Education.

Ha: There is significant impact of FDI in education on Enrolment in Higher Education.

The impact of FDI in education sector on enrolment in Higher education is measured with the help of simple linear regression analysis. The fixed regression model is, $\mathrm{Y}_{\mathrm{t}}=\mathrm{a}+\mathrm{bX} \mathrm{t}-2$

Where, $\mathrm{Y}=$ enrolment Higher education $(\%), \mathrm{X}=\mathrm{FDI}$ in Education $b=$ Regression coefficient $a=$ Constant

The results can be seen from table 3.2

Table 4: FDI in education and enrolment in Higher education

\begin{tabular}{|l|l|l|l|l|l|}
\hline Variables & $\begin{array}{l}\text { Coefficient } \\
\text { Beta }\end{array}$ & T-Value & P-Value & Correlation & $\mathbf{R}^{2}$ \\
\hline $\begin{array}{l}\text { FDI indian } \\
\text { Education } \\
\text { Sector }\end{array}$ & 0.0473077 & 2.525 & 0.039511 & 0.69042994 & 0.476694 \\
\hline
\end{tabular}

Source: Author's own calculation compilation based on table 3 
There exists a weak but positive correlation $(\mathrm{r}=0.690)$ between FDI in education and enrolment in higher education. To measure the impact of FDI in education and enrolment in higher education a hypothesis was framed that "There is no significant impact of FDI in education and enrolment in higher education ". To test the above hypothesis regression tools were used.

The regression coefficient of FDI in Education has positive impact on enrolment in higher education i.e. $1 \%$ of change in FDI in Education will bring about 0.0473077 change in enrolment under higher education keeping other variables constant. The model is significant $(p<0.05)$ and the null hypothesis will be rejected which means the FDI in education do have a significant impact on enrolment in Higher education.

\subsection{Impact of Gov't expenditure on education and} FDI in education on enrolment in higher education This section shows the combined impact of FDI in Education and government expenditure on education using the following table, table 5 ,

\begin{tabular}{|l|l|l|}
\hline $\begin{array}{l}\text { FDI in } \\
\text { education(US \$, } \\
\text { Million) }\end{array}$ & $\begin{array}{l}\text { total (enrol. } \\
\text { in higher\%) }\end{array}$ & $\begin{array}{l}\text { Gov't } \\
\text { expd.onedu. (\% } \\
\text { of GDP) }\end{array}$ \\
\hline $\mathbf{4 3 . 5 9}$ & 13.19 & 3.34 \\
\hline $\mathbf{2 1 4 . 5 2}$ & 15.12 & 3.48 \\
\hline $\mathbf{6 3 . 3 5}$ & 16.1 & 3.4 \\
\hline $\mathbf{3 7 . 9 4}$ & 17.91 & 3.56 \\
\hline $\mathbf{1 0 5 . 6 2}$ & 22.86 & 3.95 \\
\hline $\mathbf{1 7 2 . 2}$ & 24.37 & 4.05 \\
\hline $\mathbf{2 6 2 . 0 9}$ & 23.89 & 3.98 \\
\hline $\mathbf{7 8 . 8 6}$ & 25.54 & 4.35 \\
\hline $\mathbf{2 3 0 . 7 8}$ & 26.87 & 4.44 \\
\hline
\end{tabular}

Source: open government data of India and UNESCO

\section{Research hypothesis}

$\mathrm{H} 0$ : There is no significant impact of FDI in education and Gov't expenditure on Enrolment in Higher Education.

Ha: There is significant impact of FDI in education and Gov't expenditure on Enrolment in Higher Education

The impact of FDI in education sector and Gov't expenditure on education on enrolment in Higher education is measured with the help of multiple regression analysis. The fixed regression model is $\mathrm{Y}_{\mathrm{t}}=\mathrm{a}+\mathrm{bX} \mathrm{t}-2+\mathrm{cZ}_{\mathrm{t}-2}$

Where, $\mathrm{Y}=$ enrolment Higher education (\%), $\mathrm{X}=\mathrm{FDI}$ in Education $b=$ Regression coefficient of FDI in Education ,

$Z=$ gov't expenditure on education,

$c=$ regression coefficient of Gov't expenditure on education and

\section{$\mathrm{a}=$ Constant}

An important element about relationship formed is that, it included the element of time lag. The time lag is taken as 2 years.

There exists a strong positive multiple correlation between variables with $r=0.6664$. To measure the impact of FDI in education and Gov't expenditure on education on enrolment in higher education a hypothesis was framed that "There is no significant impact of FDI in education and Gov't expenditure on education on enrolment in higher education ". To test the above hypothesis regression tools were used.

The regression coefficient of FDI in Education has positive impact on enrolment in higher education i.e. $1 \%$ of change in FDI in Education will bring about 0.00238652 change in enrolment under higher education keeping other variables constant. The model is significant $(\mathrm{p}<0.0001 \& \mathrm{f}=51.39113)$ and the null hypothesis will be rejected which means the FDI in education do have a significant impact on enrolment in Higher education.

\section{Interpretation}

As per all three hypothesis, there exists a positive correlation but the impact of FDI in Education is not significant on enrolment at secondary education. However, when it comes to FDI in education on Higher Education, there is a significant impact of former upon latter. Finally, FDI in education intermixed with Government expenditure towards Higher education has the most significant impact on Enrolment at higher education. Insignificance in the first scenario lead us to the argument that there exists other indicators that could be influencing the Indian education sector and there might exist loopholes in these use of foreign finance in Indian education sector. Some factors affecting Indian education sector other than FDI could be as follows:

$>$ Parents' Education and Enterprises

$>$ Security of Girls with Disabilities

$>$ Poverty and Priority Strategies

$>$ Distance to School

$>$ Shortage of Teachers and School Environment

$>$ Unequal Treatment among Children

$>$ Socio culture \&political issues 
Though India can said to be politically stable, the country is known for frequent changes in government administration and instability in some regions or states, this issue negatively affects the education and it is threat to the education sector. Also government legislations in India are known to some extend as hindering the growth of industry especially for Universities. Some of the threats are commercialization of this sector.

\section{Challenges faced by foreign investors during 2007} $-2015$

$>$ At pre-school level, there are lack formal regulations governing the sub-sector.

$>$ The problem areas affecting the higher education level are over-centralisation, limited access and regional disparity.

$>$ The UGC regulations governing higher education require that all deemed-to-be universities shall be registered as a not-for-profit society under the Societies Registration Act, 1860 or as a not-forprofit Trust under the Public Trust Act, or as a not-for-profit company under Section 8 of the Companies Act, 2013.

$>$ The regulations also state that a private university is the one that is established through a state/central Act by a sponsoring body which is either a notfor-profit society or company.

Despite increasing FDI in education and government contribution towards education there exist certain inefficiencies in Indian Education Sector. Root cause of inefficiency in education sector includes limited focus on internationalization and research, low recognition of Indian brands, wrong perception of Indian higher education and there are complex and restrictive regulations requirements of approval from agencies to enter into collaboration. Moreover, graduates lack basic employability skills, updated curricula. Following are some of the targets set for higher educational sector in India

$>$ Develop students with international outlook and global impact.

$>$ Relax regulatory requirements

$>$ Enabling graduates with global skills.

$>$ Increasing R\&D funding by government

> Developing research focused institutes.

\section{Conclusion}

FDI in education is highly unregulated and has always been a matter of debate in India. Our nation was always socialist in its orientation. The regulating authorities could possibly look to amend the current mandatory requirement as far as the 'not-for-profit' model is concerned in order to attract increased FDI inflow in Indian Educational Sector. This will lead to a rise in FDI even in the unregulated education sector. The FDI in education is directly related to enrolment in educational sector. And it plays a significant role in enrolment at various levels of education. However, there is a need to direct our funds towards other level of education and there is a need to grow light on other factors influencing the Indian Educational sector. Moreover, government's contribution towards education combined with FDI has huge significance on the enrolment in higher education. Considering the fact that Indian Higher educational sector is third largest sector in the world can further improvise when a combined effort works towards improving it. By improving our international relation and creating a investment conducive environment FDI can be further increased.

\section{Reference}

1. Awasthi, Alka. "Impact Of Foreign Direct Investment On Higher Education." International Journal Of Research Granthaalayah, vol. 4, no. 5, 2016.

2. Deloitte."Indian Higher Education Sector Opportunities Aplenty, Growth Unlimited."Deloitte.

3. Government Of India. "Financial Year Wise FDI Equity Inflow From 2000-01 To 201516." National Data Sharing And Accessibility Policy.

4. Ministry Of Statistics And Programme Implementation, Government Of India .

5. Narang, Viney, and Anshu Jain. "FDI In Education Sector: Issues, Prespects And Future Implications." International Journal Of Innovative Research And Development, vol. 3, no. 1, 2014.

6. Singh, Kalpana, and AlkaAwasthi. "Impact Of Foreign Direct Investment On Higher Education." International Journal Of Research Granthaalayah, vol. 4, no. 5, 2016

7. Sultana, Sameera. "Study On Foreign Direct Investment In Education." International Journal Of Advance Trends In Computer Science And Engineering, vol. 2, no. 1, 2013.

8. UNESCO INSTITUTE FOR STATISTICS, United Nations Education Scientific And Cultural Organization. 